
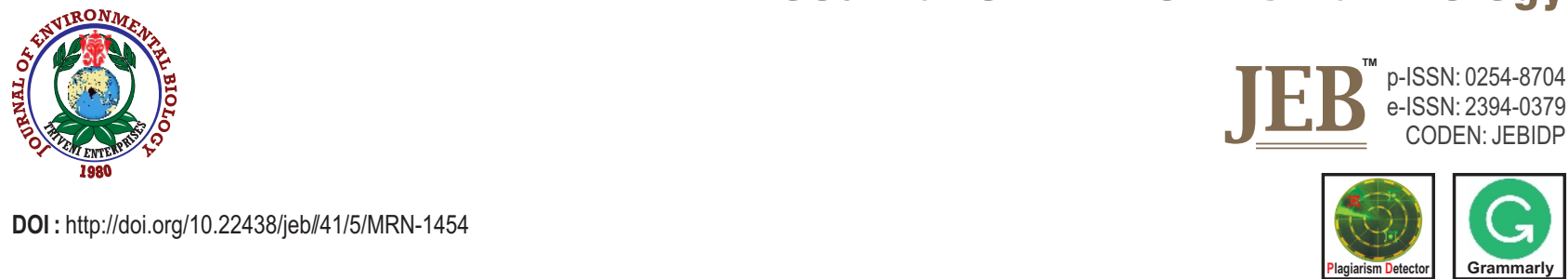

\title{
Mediterranean Riparian Areas-Climate change implications and recommendations
}

\author{
G.N. Zaimes \\ UNESCO Chair Con-E-Ect, Department of Forest \& Natural Environment Sciences, International Hellenic University, Drama-66100, Greece \\ *Corresponding Author Email : zaimesg@teiemt.gr
}

\section{Abstract}

Riparian areas are unique ecosystems and ecotones that provide many ecosystem services. Their importance is even larger in dryland areas because of the water scarcity conditions. This is especially true in the Mediterranean region where their value has been recognized and utilized for thousands of years. This utilization has led to severe their degradation, and in many cases, elimination. The Mediterranean Basin is also considered one of the most sensitive regions to climate change impacts. In this review, review, firstly the characteristics of the riparian areas of the region were identified, based on its climatic and geographic conditions but also anthropogenic impacts. Secondly, the potential impacts of climate change on riparian areas were assessed by understanding the associated effects on the hydrologic regimes of rivers. Flow patterns are expected to become flashier with greater periods of drought and peak flows with higher magnitudes.

This should impact the ecological processes of riparian areas and their vegetation assemblages and exacerbate the existing pressures they already face due to the numerous and diverse

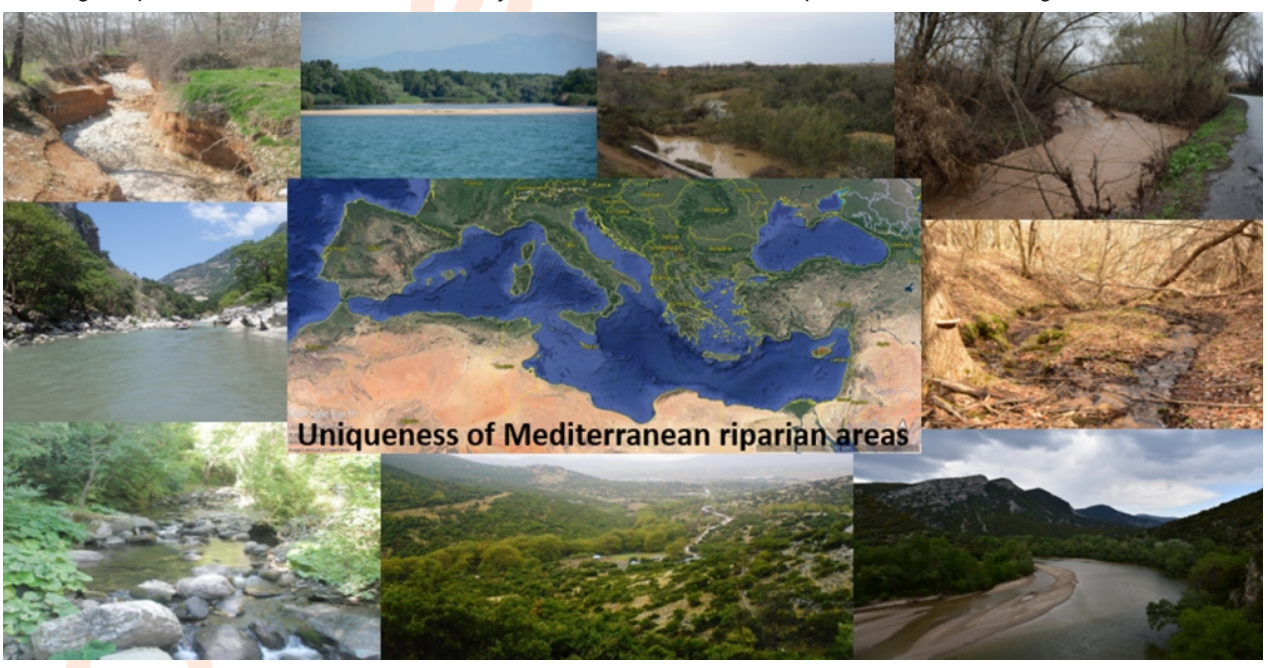
anthropogenic activities in the region. Based on the current and future conditions, it is imperative that measures should be taken to protect and reestablish riparian corridors in the Mediterranean. Although many areas are protected by initiatives such as the Natura 2000 Network or the the Ramsar Convention, additional and innovative practices need to be implemented. Specifically, the adoption of ecosystem-based approaches such as naturebased solutions and soil and water bioengineering are recommended because they take into consideration the ecosystem services of riparian areas. Even when practices are implemented at a local scale, they need to adopt a watershed scale approach to understand the drivers of riparian areas and the impacts from anthropogenic activities. The key for the successful restoration of riparian areas is restoring the natural hydrologic and geomorphologic regimes. Finally, the methods utilized need to have a transdisciplinary approach that involves academics, policy makers, local experts and stakeholders.

Key words: Ecotones, Ecosystem services, Hydrologic regime, Mediterranean region, Riparian areas

How to cite : Zaimes, G.N.: Mediterranean Riparian Areas- Climate change implications and recommendations. J. Environ. Biol., 41, 957-965 (2020). 


\section{Introduction}

Riparian areas are semi-aquatic ecosystems, ecotones or transition zones; the area where the two adjacent ecosystems, the terrestrial and the aquatic, meet and integrate (Naiman et al., 2005). Spatially, they commence from the top of the canopy all the way down to the groundwater, from the edge of the aquatic ecosystem to the beginning of the terrestrial and along the length of the water body as one moves from the upstream mountainous areas to the downstream lowland areas and eventually, to the delta (Ilhardt et al., 2000). Typically, riparian areas, are linear in shape which extend adjacent to streams and rivers with complex assemblages of plants and other organisms that change through time and space (Lowrance et al., 1985). The riparian area widths are narrower along a small stream than adjacent to a large river. This has to do with the "zone of influence," the zone of the terrestrial area that is influenced by the adjacent aquatic ecosystem (National Research Council, 2002). Finally, these ecosystems are azonal because they can be found in all biomes and along the entire altitudinal gradients from high mountains to seacoasts (Baker et al., 2003).

The definition utilized for riparian areas in this review is based on the National Research Council (2002) that states they are transitional zones between aquatic and terrestrial ecosystems; have biophysical, ecological and biota gradients; connect through surface and subsurface hydrology the uplands to the adjacent waterbodies; influence exchanges of energy and matter between terrestrial and aquatic ecosystems (zone of influence) and are adjacent to perennial, intermittent and ephemeral streams, lakes, and estuarine-marine shorelines. Riparian areas are distinguished from the adjacent terrestrial ecosystems due to the presence and influence of excess water from the aquatic ecosystem (Zaimes et al., 2010; Arthun and Zaimes, 2020). These areas are also disturbance driven ecosystems, such as from floods and droughts (Lowrance et al., 1985; Naiman et al., 2005; National Research Council 2002). The unique hydrologic, soil and geomorphologic conditions lead to the distinctive and diverse riparian vegetation assemblages that can include trees, shrubs, grasses and forbs (Zaimes et al., 2019c). The vegetation is hydrophilic because it prefers higher soil moisture conditions and can withstand periods of flooding. In riparian areas, one can see different vegetation gradients while moving from the aquatic ecosystem to the terrestrial one (Schismenos et al., 2019; Stella et al., 2013). Differences in vegetation can also be seen depending on the dominant geomorphic processes at a specific location (Emmanouloudis et al., 2017). For example, on the outside bend of the meander were erosion occurs the vegetation will differ from the vegetation on the inside were deposition occurs (sand bar).

The uniqueness of riparian ecosystems is the reason for the many ecosystem services they offer (Zaimes et al., 2019a). Some of the most important services they offer are (Mediterranean Wetland Outlook 2 2018; Schultz et al., 2004; Srivastava and Singh, 2012; Zaimes et al., 2011a, 2019e): provision of flood storage and reduction of flood magnitudes; reduction of surface and stream bank erosion; reduction of sediment loadings in water bodies; provision of groundwater recharge; production of natural crops; filtering, treating and preventing non point source pollutants; provision of habitat for birds, amphibians, reptiles, mammals and insects; provision of ecotourism opportunities; provision of habitat for rare, endangered and threatened species; carbon maintenance and sequestration; mitigation of climate change and of the urban heat island effects; provision of recreational opportunities and scenic beauty; provision of historical, archaeological, heritage and cultural opportunities, since many riparian areas have been inhabited for thousands of years; provision of educational and interpretive opportunities and provision of scientific research opportunities.

Wetlands, deltas and riparian areas are ecotones between aquatic and terrestrial ecosystems (National Research Council, 1995, 2002; Emmanouloudis et al., 2017). These ecotones have similarities but are different ecosystems. Riparian areas include terrestrial areas that are saturated or inundated with water for short period of time. Most wetlands are under water year around and always have hydric soils. Riparian areas can have non-hydric soils. Finally, most riparian areas are highly connected with each other, linear in shape, high in energy because they are disturbance driven that support woody plants and emergent herbaceous plant cover. In contrast, wetlands support more frequently, deeper water submerged aquatic plants, are lightly connected with each other, oblong or circular in shape and with less intensive and frequent disturbances. Finally, deltas are confined at the mouth of streams or rivers as they enter a large water body (lake or sea), have multiple channels that shift through time and include both riparian areas and/or wetlands. Several ecosystem services of riparian areas have led to their conservation and sustainable management, especially in developed countries. In the Mediterranean region, despite their importance and significant degradation necessary research has not been conducted (Zaimes et al., 2011a; Zogaris et al., 2009). The aim of the study was to assess the major anthropogenic disturbances of riparian areas in the Mediterranean and review the impending climate change impacts of these ecosystems and recommended best practices for the region to better adapt to climate change impacts.

\section{Mediterranean Riparian Areas}

The Mediterranean includes 27 countries of Southern Europe, Northern Africa and the Middle East. It occupies about 2.3 million $\mathrm{km}^{2}$ area and experiences Mediterranean climate more than 400 million inhabitants (Olson et al., 2001). The climate is warm to hot and dry in the summer and mild to cool and wet in the winter. Temperature variation between summer and winter is relatively small because of their proximity to the Mediterranean Sea. The region also has a mosaic topography with flat areas along the seacoast and large and tall mountain ranges nearby, that influences hydrologic, vegetative and climatic regimes (Emmanouloudis et al., 2011). The specific climatic 
characteristics depend on the latitude, altitude and distance from the sea. The climatic and topographic conditions along with the natural, frequent wildfires (Pausas and Lloret, 2007) and human impacts have led to this unique and highly biodiverse biome. Many consider it as the most heavily degraded because it has been inhabited by humans for thousands of years (Savopoulou et al., 2017). Their negative impacts are evident with the many unsustainable agricultural lands and the few remaining natural ecosystems (Zaimes and Emmanouloudis, 2012).

Since the focus is on riparian areas, there is a need to understand the adjacent water bodies of the region. The rivers and streams have natural high flow variability with wet winters and floods to severe droughts during summers (Cid et al., 2017; Zaimes et al., 2010). Mediterranean streams, located in high altitudes have annual rainfall greater than $1000 \mathrm{~mm}$, and low temperatures in winter with snow accumulation in many cases. They have perennial flow and the highest flow occurs after rain and snowmelt in spring (Lobera et al., 2016). In contrast, streams located in semi-arid areas (lowland areas), have annual precipitation from 200 to $500 \mathrm{~mm}$, with intermittent or ephemeral flow (Lobera et al., 2016). This second type of streams are called "torrents" in the Southern Europe and "wadis" in the Middle East and North Africa (Emmanouloudis et al., 2011). Torrents, compared to rivers, have more irregular flow that can change in hours from no flow to a flash flood event. These floods are characterized by large volume of water and high amount of sediments travelling at high speeds (Emmanouloudis et al., 2011). Wadis in Arabic refer to a valley but can also refer to a dry river bed with ephemeral flow (Sen, 2019; Ouhamdouch et al., 2020; Emam et al., 2019). Wadis are located below alluvial fans that extend on gently sloping, nearly flat parts of the deserts. They have a braided pattern with no permanent channels. When water flows, it eventually infiltrates into the stream bed leading to extensive sediment deposits. The riparian areas of the region are typically adjacent to these types of streams that has led to their unique characteristics.

The vegetation assemblages of Mediterranean riparian areas are impacted by the climatic, hydrologic and geomorphologic characteristics. These characteristics lead to rich and dynamic riparian plant communities, with interannual fluctuations in richness and composition that differ and are more diverse that those of temperate riparian areas (Sabater et al., 2008; Feio et al., 2014; Kontsiotis et al., 2019; Ferreira et al., 2019). Their vegetation can vary for woody vegetation to herbaceous and mixtures. During dry season, groundwater is the only source of water for the stream/river reaches (Argyroudi et al., 2009). Reduced groundwater inputs can lead to droughts that cause habitat loss, poor water quality and biotic interactions. The vegetation assemblages of the Mediterranean have shorter life spans, desiccation resistance or avoidance mechanisms, and high colonization rates (Bonada et al., 2007; Santos, 2010). Finally, natural and human disturbances, shape riparian plant communities, making it difficult to find undisturbed plant communities. The Habitats Directive (92/42/CEE) has categorized six major Mediterranean riparian habitat types
(Zogaris et al., 2007; Zaimes et al., 2010): i) Alluvial forests with Alnus glutinosa and Fraxinus excelsior (Alno-Pandion, Alnion incanae, Salicion albae ); code: 91 E0. ii) Riparian mixed forests of Quercus robur, Ulmus laevis and Ulmus minor, Fraxinus excelsior or Fraxinus angustifolia, along major rivers (UImenion minoris); code: 91F0. iii) Salix alba and Populus alba galleries; code: 92A0. iv) Platanus orientalis and Liquidambar orientalis woods (Plantanion orientalis); code: 92C0. v) Southern riparian galleries and thickets (Nerio-Tamaricetea and Securinegion tinctoriae); code: 92D0. vi) Riparian formations on intermittent Mediterranean water courses with Rhododendron ponticum, Salix and others; code: 92B0.

Major anthropogenic impacts on Mediterranean riparian areas: Humans have occupied the Mediterranean for thousands of years and utilized the ecosystem services of riparian areas, leading to their degradation (Table 1) (Zaimes and Emmanouloudis, 2012; Geijzendorffer et al., 2019). The region has limited water resources and a strong population growth (United Nations, 2013). The agricultural areas and human activities of the region has expanded and increased from 2000 to 2015 (FAO and Plan Bleu, 2018). Agriculture is the number one user of freshwater in the region but there is a transition from nonirrigated to permanently irrigated crop lands (Malek et al., 2018). Urban population continues to grow that should impact riparian areas, since many cities and towns are along streams, rivers or deltas (García-Nieto et al., 2018). Furthermore, the increase in seasonal tourism in most Mediterranean countries, multiplies the population in coastal regions during summer (Gober, 2010; Collet et al., 2014). Overall, human activities will further exacerbate pressure on water resources and riparian areas in the next decades (Ferreira et al., 2019).

This land use intensification by agriculture and urban expansions has eliminated and/or simplified riparian ecosystems richness, structural diversity and quality (Corbacho et al., 2003; Bruno et al., 2014b). This intensification has led to their fragmentation in the lowlands of the Mediterranean, compared to the mountainous areas (substantially less agricultural activities) with negative effects on their ecosystem services (Zaimes et al., 2011a). Mediterranean streams and rivers, due to strong seasonal and annual variability of the flow regimes, have been heavily regulated (Garófano-Gomez et al., 2011; Grantham et al., 2013). More than 3500 dams have been built during the $20^{\text {th }}$ century (Lobera et al., 2016). Dams and flood protection infrastructures lead to a more constant flow regime that alters the natural hydrologic regime, sediment transport capacity and dynamics, water chemistry, thermal regime and connectivity (Nilsson et al., 2005; Bernal et al., 2013; Bonada and Resh, 2013; Garófano-Gomez et al., 2011) and disrupt the structure and composition of plant communities (Dufour et al., 2007, Papastergiadou et al., 2016; Bombino et al., 2019; Zaimes et al., 2019b). These changes cause ecological degradation, damaging the availability and quality of the habitat leading to a decrease in both species' richness and health of aquatic and riparian biota (Vericat and Batalla, 2006; Gendaszek et al., 2012; Lobera et al., 
Table 1: The main pressures that riparian areas of the Mediterranean face, the knowledge gaps and recommended measures for their more sustainable management

\begin{tabular}{|c|c|c|}
\hline Pressures & Knowledge Gaps & Recommendations \\
\hline Long history of human disturbances & Shifts in riparian structure after human impacts & Protect and conserve natural riparian areas \\
\hline Limited freshwater resources & Cause-effect of human activities on riparian communities & Preserve natural streamflow variability \\
\hline Population increase & Effects of scale, land use heterogeneity, and high temporal & Enhance aquifer water recharge \\
\hline $\begin{array}{l}\text { Land cover and vegetation cover } \\
\text { changes }\end{array}$ & hydrological variability on management & Re-establish riparian ecosystems \\
\hline Agriculture - Cultivation & Human impacts on the surface-groundwater & $\begin{array}{l}\text { Restore hydrologic and geomorphologic } \\
\text { regimes }\end{array}$ \\
\hline Agriculture - Grazing & Riparian community resilience to climate change & Large-scale watershed approaches \\
\hline Urbanization & Water body and riparian condition, links and functions & $\begin{array}{l}\text { Collection of datasets at large spatial and } \\
\text { temporal scales }\end{array}$ \\
\hline $\begin{array}{l}\text { Dam and flood protection } \\
\text { infrastructures }\end{array}$ & $\begin{array}{l}\text { Relationships between riparian areas and } \\
\text { hydrogeomorphic drivers }\end{array}$ & $\begin{array}{l}\text { Ecosystem-based approaches (nature- } \\
\text { based solutions, soil \& water bioengineering) }\end{array}$ \\
\hline Alteration of hydrologic regimes & Why restoration initiatives have low success rates & Use of ecosystem level tools \\
\hline Groundwater withdrawal & Information on ecosystems-based approaches & $\begin{array}{l}\text { Establish wide, healthy and diverse } \\
\text { riparian zones }\end{array}$ \\
\hline Water Pollution & Interactions among native \& introduced species & $\begin{array}{l}\text { Knowledge transfer to stakeholders \& } \\
\text { decision makers }\end{array}$ \\
\hline Invasive Species & Response capacity of riparian areas to multiple stressors & Stakeholder's involvements \\
\hline Climate Change & & Transdisciplinary approach \\
\hline Tourism & & $\begin{array}{l}\text { Measure adaptation by stakeholders } \\
\& \text { decision makers }\end{array}$ \\
\hline
\end{tabular}

2016; Bruno et al., 2014b). Groundwater withdrawal or major changes in land cover, primarily for agriculture, can result in reduced subsurface inflow to streams, changes in groundwater dynamics, and degradation of the riparian areas (Benejam et al., 2008; Mencio and Mas-Pla, 2010). The need for water abstraction continues to rise, especially in the Mediterranean islands that are largely dependent on groundwater (Koutroulis et al., 2013). Groundwater depletion leads to low or nil stream flows, especially during summers, but also decrease surface water quality, by decreased dilution of pollutants (Moustadraf et al., 2008; Mencio and Mas-Pla, 2010). The decrease in water quality is also due to intensified agriculture, increased urbanization and loss of riparian areas (Zaimes et al., 2019e). The increase of non-point source pollutants causes eutrophication of freshwater ecosystems (Navarro-Ortega et al., 2015).

Alteration to the hydrologic regime, the increase in pollution and changes in the functionality of streams, rivers and riparian areas have led to the increase and expansion of invasive species (Jiménez-Ruiz and Santín-Montanyá, 2016). Invasive species further degrade riparian habitats (Van den Broeck et al., 2015; Rouissi et al., 2018; Fraixedas et al., 2019). The new environmental conditions in the riparian ecosystems are more tolerable, in some cases, to invasive species. Alteration of the vegetative structure, competitive displacement of native riparian vegetation, reduction of arthropod and avian diversities, abundances and homogenization are some major impacts of invasive species (Bruno et al., 2019; Herrera and Dudley, 2003). Examples of invasive species posing serious threats and problems in the Mediterranean riparian areas are Robinia pseudoacacia, Ailanthus altissima and Arundo donax (Bruno et al., 2019; Nadal-Sala et al., 2019; Constán-Nava, 2015). Overall, the riparian vegetation of the Mediterranean basin has decreased with increasing drought, flow regulation and agricultural activities (cultivation, grazing) (Bruno et al., 2016; Aguiar et al., 2018). This long history of human disturbances (Feio et al., 2014) is the reason why Mediterranean river ecosystems have a highly endangered biodiversity, with $40 \%$ of the fish species being endangered (Mediterranean Wetlands Outlook 2, 2018).

Climate change, hydrologic regimes and riparian areas in the Mediterranean: The Mediterranean region is one of the most vulnerable to global change. Projections in the region forecast intensification of the hydrological cycle through increase in temperature, concentration of rainfall in shorter periods of the year, decline in precipitation up to $50 \%$ in summer, and increase in drought frequency and strength (Terrado et al., 2014; Rault et al., 2019). In addition, the decrease of the average river discharge and increase in water temperature and frequency of large floods in the region have been forecasted (Calbo, 2010). River discharges are estimated to decrease by 7 to $30 \%$ by the end of $21^{\text {st }}$ century (Lelieveld et al., 2012). In the Mediterranean, negative trends in runoff have been observed in rivers located in Greece (Giakoumakis and Baloutsos, 1997), the Balkans (Genev, 2003; Rivas and Koleva-Lizama, 2005), Lebanon (Shaban, 2009), Turkey (Kahya and Kalayci, 2004) and Spain (Ceballos et al., 2008). Most Mediterranean watersheds have snow-fed mountain springs. Hence, an increase in temperature will result in less snow accumulation and more rapid snow melt. These changes in the headwaters, and the increase in 
evapotranspiration should lead to higher winter and lower spring discharges and lower summer flows (Van den Broeck et al., 2015). The hydrologic models based on different climate change scenarios predict intensification of low or no flow periods in many countries of the Mediterranean such as France (Lespinas et al., 2014), Italy (Piras et al., 2015), Spain (Majone et al., 2012), Portugal (Mourato et al., 2015), Morocco and Tunisia (Tramblay et al., 2016; Marchane et al., 2017), Israel, Syria and Lebanon (Smiatek et al., 2014). A common scenario is, headwaters becoming intermittent or even ephemeral, while lowland aquifers are depleted and/or polluted (Choukr-Allah et al., 2017). With climate change impacts on hydrology and increasing water demand due to growing population, the shift from perennial streams to intermittent and intermittent to ephemeral is likely to increase (Iglesias et al., 2012). The increased pressure on shrinking water resources will compound the impacts on river and adjacent riparian ecosystems (Navarro-Ortega et al., 2015). The variety of riparian plant communities found in natural floodplains is mainly controlled by the flow regime and fluvio-geomorphologic events (Belmar et al., 2013; Leo et al., 2019; Zaimes et al., 2019b). This interaction between flow-biota is astounding in the Mediterranean rivers due to their increased biological diversity and highly variable flow regimes (Zaimes etal., 2010; Garófano-Gomez etal., 2013).

Many native riparian species have developed life cycles adapted to seasonal peak flows. The loss of seasonal flows may hinder the regeneration of these communities, reducing growth rates or favoring invasive species. Lateral connectivity of the riparian areas is also altered by reducing the frequency, magnitude and duration of floods (Charlton, 2008), causing loss of native riparian vegetation (Garófano-Gomez et al., 2011; Zaimes et al., 2019b). Severe droughts (longer, unpredictable, a seasonal or supra-seasonal droughts) due to climate change, will stress and deplete both native fauna and flora (Bond et al., 2008; Mencio and Mas-Pla, 2010). Overall, more riparian areas, typically adjacent to intermittent and ephemeral streams, are expected to be prevalent with the significant reduction of riparian areas with characteristics of those adjacent to perennial streams.

Recommended measures for Mediterranean riparian areas: Maintaining or re-establishing riparian ecosystems is essential in the Mediterranean because most have experienced intensive land-use changes and other human disturbances for thousands of years (Table 1) (Corbacho et al., 2003; Zaimes et al., 2010). The growing human demands for water, are increasing the frequency and severity of water scarcity, leading to insufficient water supplies to support human and ecosystem needs (Bond et al., 2019). Few studies have focused on shifts in the structure of riparian communities after human-induced hydrogeomorphic changes in the Mediterranean (Table 1) (Aguiar et al., 2001; Salinas and Casas, 2007). The cause-effect of human activities on riparian communities needs to be determined while incorporating the effects of scale, land use heterogeneity, and high temporal hydrological variability on management and restoration practices (Cooper et al., 2013). The preservation of natural streamflow variability should be a priority while human impacts on the surface water-groundwater relationship should also be better understood in the Mediterranean (Mencio and MasPla, 2010; Cid et al., 2017). Aquifer water storage and base flow generation alterations have significant effects on stream and riparian habitats. The importance of restoring riparian areas in the region is recognized, because numerous riparian areas have been designated as protected by the Habitat Directive (92/43/EEC) and the Ramsar Convention (Zaimes et al., 2010; Ferreira et al., 2019). The Water Framework Directive (WFD; 2000/60/EC), obligates European Union (EU) countries to assess the features of their riparian areas (Van den Broeck et al., 2015; Magdaleno and Martinez, 2014). Despite these initiatives, many riparian areas continue to be threatened by human activities that reduce their area and deteriorate their quality. Most restoration initiatives have low success rates in re-establishing the same richness and stability found in natural riparian areas.

Successful management measures need to follow a large-scale hydrological approach to determine the origin of habitat variations and human pressures (Mencio and Mas-Pla, 2010). Conservation and restoration efforts carried out at local scale need to take into account land use, hydrologic and geomorphologic characteristics at the watershed scale (Bruno et al., 2014a, b). In addition, the ecological restoration actions are hindered due to water scarcity in the Mediterranean (Cortina et al., 2011; Vallejo et al., 2012). More ecosystem-based approaches are being implemented in the region (Nunes et al., 2016) such as nature-based solutions and soil and water bioengineering. Nature-based solutions can maintain riparian biodiversity and provide critical ecosystem services (Balzan et al., 2019). To implement these approaches, information on the accumulated experiences of such efforts throughout the Mediterranean should be collected and analyzed (Zaimes et al., 2019d).

Sustainable management plans need to incorporate the relationships between the structure of riparian woodlands and their hydrogeomorphic drivers (Cid et al., 2017). Databases, at large spatial and temporal scales, are key to understand the variability of hydrology and ecology of riparian ecosystems (Hannah et al., 2011). However, such databases are scarce in the Mediterranean, despite efforts to develop data networks. The extreme contrasts in climate, topography, geology, population distribution and water use, especially in river regulated water bodies, in the Mediterranean lead to diverse physical and human characteristics at the watershed scale (Collet et al., 2014). Longterm data sets are also important to understand the interactions among native species and introduced species, especially for extreme events such as drought and floods (Magalhães et al., 2007). Such studies, particularly in regulated systems, help guide flow recommendations to benefit native species (Kiernan et al., 2012; Resh et al., 2013). Measures should be taken to recover the hydrogeomorphic regimes to achieve self-sustainability of riparian ecosystems (González et al., 2010). The water body and riparian condition, links and functions need to be further investigated, taking into consideration the impacts of water and riparian management for ecosystem services (Acreman et al., 
2014). Tools at the ecosystem level, connecting ecosystem condition to services, are required especially in climate change scenarios. In most cases, a wide, healthy and diverse riparian zone acts as a buffer for water bodies, minimizing intensive agriculture and other anthropogenic activities effects (Zaimes et al., 2011b; lakovoglou et al., 2013). Finally, the success of restoring policies depend on riparian ecosystem and climate change information transferred and adopted by the stakeholders and decision makers (Betzold, 2015; La Jeunesse et al., 2015).

The projected water scarcity and riparian areas degradation in the region highlight the importance to implement innovative water and habitat practices (Hejazi et al., 2014) and strategic resources planning from global to regional and local scales (Koutroulis et al., 2013). Stakeholders, the beneficiaries of ecosystem services, play a key role in interpreting climate change impacts on riparian areas. A methodology based on a transdisciplinary approach with the involvement of academics, policy makers, and local experts is suggested. Many physical models on climate change impacts on water scarcity exist, however, transdisciplinary approaches with local stakeholders' involvement are limited (Rault et al., 2019). Improving the understanding of capacity of ecosystem responses to multiple stressors and defining measures to improve the ecological status of riparian areas are needed (Mencio and Mas-Pla 2010). This transdisciplinary approach will lead to greater acceptance of suggested policies and practices by the stakeholders and a higher rate of successfully restoring the riparian ecosystems and adjacent water bodies.

The pressure on riparian areas of the Mediterranean region in the future, will only continue to grow. It is imperative that actions and measures should be taken to ensure their ecosystem services for future generations. Riparian areas are resilient and with proper measures can be maintained and restored. Implementation of watershed, ecosystem-based and transdisciplinary approaches are few measures that should be promoted for the enhanced conservation and protection of these ecosystems. Finally, the key is the involvement of stakeholders and decision makers for the faster and more wide acceptance and implementation of these approaches.

\section{References}

Acremman, M., A.H. Arthington, M.J. Colloff, C. Couch, N.D.Crossman, F. Dyer, I. Overton, C.A. Pollino, M.J. Stewardson and W. Young: Environmental flows for natural, hybrid, and novel riverine ecosystems in a changing world. Front. Ecol. Environ., 12, 466$473(2014)$.

Aguiar, F.C., P. Segurado, M.J. Martins, M.D. Bejarano, C. Nilsson, M.M. Portela and D.M. Merritt: The abundance and distribution of guilds of riparian woody plants change in response to land use and flow regulation. J. Appl. Ecol., 55, 2227-2240 (2018).

Aguiar, FC, M.T. Ferreira and I. Moreira: Exotic and native vegetation establishment following channelization of a Western Iberian River. Regul. Rivers: Res. Manage., 17, 509-526 (2001).

Argyroudi, A., Y. Chatzinilolaou, K. Poirazidis and M. Lazaridou: Do intermittent and ephemeral Mediterranean rivers belong to the same river type? Aquat. Ecol., 43, 465-476 (2009).

Arthun, D. and G.N. Zaimes: Channel changes following human activity exclusion in the Riparian Areas of Bonita Creek, Arizona, USA. Landsc. Ecol. Eng., 16, 263-271 (2020).

Baker, Jr., M.P.F. Ffolliott, L. F. DeBano and D. G. Neary (Eds.): Riparian Areas in the Southwestern United States: Hydrology, Ecology and Management. Lewis Publ. Boca Raton, FL., USA (2003)

Balzan, M.V., A.M. Pinheiro, A. Mascarenhas, A. Morán-Ordóñez, A. Ruiz-Frau, C. Carvalho-Santos, I. Vogiatzakis, J. Arends, J. Santana-Garcon, J.V. Roces-Díaz, L. Brotons, C.S. Campagne, P. Roche, S. de Miguel, S. Targetti, E. Drakou, V. Vlami, F. Baró and I. Geijzendorffer: Improving ecosystem assessments in Mediterranean social-ecological systems: A DPSIR analysis. Ecosyst. People, 15, 136-155 (2019).

Belmar, O., D. Bruno, F. Martínez-Capel, J. Barquín and J. Velasco: Effects of flow regime alteration on fluvial habitats and riparian quality in a semiarid Mediterranean basin. Ecol. Indic., 30, 52-64 (2013).

Benejam, L., E. Aparicio, M.J. Vargas, A. Vila-Gispert and E. GarcíaBerthou: Assessing fish metrics and biotic indices in Mediterranean stream: Effects of uncertain native status of fish. Hydrobiologia, 603, 197-210 (2008).

Bernal, S., D. von Schiller, F. Sabater and E. Martí: Hydrological extremes modulate nutrient dynamics in Mediterranean climate streams across different spatial scales. Hydrobiologia, 719, 31-42 (2013).

Betzold, C.: Adapting to climate change in small island developing states. Climate Change, 133, 481-489 (2015).

Bombino, G. D.A. Zema, P. Denisi, M.E. Lucas-Borja, A. Labate and S.M. Zimbone: Assessment of riparian vegetation characteristics in Mediterranean headwaters regulated by check dams using multivariate statistical techniques. Sci. Total Environ., 647, 597607 (2019)

Bonada, N., S. Dolédec and B. Statzner: Taxonomic and biological trait differences of stream macroinvertebrate communities between Mediterranean and temperate regions. Implications for future climatic scenarios. Global Change Biol.,13, 1658-1671 (2007).

Bonada, N. and V.C. Resh: Mediterranean-climate streams and rivers: Geographically separated but ecologically comparable freshwater systems. Hydrobiologia, 719, 1-29 (2013).

Bond, N. R., R.M. Burrows, M.J. Kennard and S.E. Bunn: Water Scarcity as a driver of multiple stressor effects. In: Multiple Stressors in River Ecosystems: Status, Impacts and Prospects for the Future (Eds.: S. Sabater, A. Elosegi and R. Ludwig). Elsevier, Amsterdam, Netherlands, pp.111-129 (2019).

Bond, N.R., P.S. Lake and A.H. Arthington: The impacts of drought on freshwater ecosystems: An Australian perspective. Hydrobiologia, $600,3-16(2008)$

Bruno, D., O. Belmar, D. Sanchez-Fernandez and J. Velasco: Environmental determinants of woody and herbaceous riparian vegetation patterns in a semi-arid Mediterranean basin. Hydrobiologia, 730, 45-57 (2014a).

Bruno, D., O. Belmar, D. Sanchez-Fernandez, S. Guareschi, A. Millan and J. Velasco: Responses of Mediterranean aquatic and riparian communities to human pressures at different spatial scales. Ecol. Indic., 45, 456-464 (2014b).

Bruno, D., C. Gutierrez-Canovas, D. Sanchez-Fernandez, J. Velasco and C. Nilsson: Impacts of environmental filters on functional redundancy in riparian vegetation. J. Appl. Ecol., 53, 846-855 (2016).

Bruno, D., V. Zapata, S. Guareschi, F. Picazo, E. Dettori, J.A. Carbonell, A. Millán, J. Velasco and F. Robledano: Short-term responses of aquatic and terrestrial biodiversity to riparian restoration measures designed to control the invasive Arundo donax L. Water (Switzerland), 11, 2551 (2019). 
Calbo, J.: Possible climate change scenarios with specific reference to mediterranean regions. In: Water Scarcity in the Mediterranean (Eds.: S. Sabater and D. Barceló). Springer, Berlin, pp. 1-13 (2010).

Ceballos, A., E. Morán-Tejeda, M.A. Luengo-Ugidos and J.M LlorentePinto: Water resources and environmental change in a Mediterranean environment: The south-west sector of the Duero river basin (Spain). J. Hydrol., 351, 126-138 (2008).

Charlton, R.: Fundamentals of fluvial geomorphology. Routledge. New York, NY, USA(2008).

Choukr-Allah, R., R. Ragab, L. Bouchaou and D. Barceló (Eds.): The Souss-Massa River Basin, Morocco. The Handbook of Environmental Chemistry. Springer, Cham, Switzerland (2017).

Cid, N., N. Bonada, S.M. Carlson, T.E. Grantham, A. Gasith and V.H. Resh: High variability is a defining component of Mediterraneanclimate rivers and their biota. Water, 9, 52 (2017).

Collet, L., D. Ruelland, V. Borrell-Estupina and E. Servat: Assessing the long-term impact of climatic variability and human activities on the water resources of a meso-scale Mediterranean catchment. Hydrolog. Sci. J., 59, 1457-1469 (2014).

Constán-Nava, S., S. Soliveres, R. Torices, L. Serra and A. Bonet: Direct and indirect effects of invasion by the alien tree Ailanthus altissima on riparian plant communities and ecosystem multifunctionality. Biol. Invasions, 17, 1095-1108 (2015).

Cooper, S. D., P. S. Lake, S. Sabater, J. M. Melack and J.L. Sabo: The effects of land use changes on streams and rivers in Mediterranean climates. Hydrobiologia, 719, 383-425 (2013).

Corbacho, C., J.M. Sanchez and E. Costillo: Patterns of structural complexity and human disturbance of riparian vegetation in agricultural landscapes of a Mediterranean area. Agric. Ecosyst. Environ., 95, 495-507 (2003)

Cortina, J., B. Amat, V. Castillo, D. Fuentes, F.T. Maestre, F.M. Padilla, and L. Rojo: The restoration of vegetation cover in the semi-arid Iberian southeast. J. Arid Environ., 75, 1377-1384 (2011).

Dufour, S., N. Barsoum, E. Muller and H. Piegay: Effects of channel confinement on pioneer woody vegetation structure, composition and diversity along the River Drome (SE France). Earth Surf. Proc. Land., 32, 1244-1256 (2007).

Emam, W.M., M.S. Darwish and M.R. Haggag: Watershed management as a mechanism to confront flood disasters in Egypt.J. Eng. Appl. Sci., 66, 133-155 (2019).

Emmanouloudis, D., G.N Zaimes and V. lakovoglou: UNESCO Chair ConE-Ect: Promoting conservation in riparian and deltaic ecosystems. Procedia Environ. Sci. Eng. Manag., 4, 235-243 (2017)

Emmanouloudis, D., J.L. Garcia Rodriguez, G.N. Zaimes, M.C. Giminez Suarez and E. Filippidis: Euro-Mediterranean torrents: Case studies on tools that can improve their management. In: Mountain Ecosystems: Dynamics, Management and Conservation (Ed.K.E. Richards). Nova Science Publishers, Hauppauge, NY, USA, pp. 144 (2011).

FAO and Plan Bleu: State of Mediterranean Forests. Food and Agriculture Organization of the United Nations, Rome, Italy and Plan Bleu, Marseille, France (2018).

Feio, M.J., F.C. Aguiar, S.F.P. Almeida, J. Ferreira, M.T. Ferreira, C. Elias, S.R.Q. Serra, A. Buffagni, J. Cambra, C. Chauvin, F. Delmas, G. Dörflinger, S. Erba, N. Flor, M. Ferréol, M. Germ, L. Mancini, P. Manolaki, S. Marcheggiani, M.R. Minciardi, A. Munné, E. Papastergiadou, N. Prat, C. Puccinelli, J. Rosebery, S. Sabater, S. Ciadamidaro, E. Tornés, I. Tziortzis, G. Urbanič and C. Vieiria: Least disturbed condition for European Mediterranean rivers. Sci. Total Environ., 476-477, 745-756 (2014).

Ferreira, M.T., L. Globevnik and R. Schinegger: Water stressors in Europe: New threats in the old world. In: Multiple Stressors in River Ecosystems: Status, Impacts and Prospects for the Future (Eds.:
S. Sabater, A. Elosegi and R. Ludwig). Elsevier, Amsterdam, Netherlands, pp.131-137 (2019).

Fraixedas, S., T. Galewski, S. Ribeiro-Lopes, J. Loh, J. Blondel, H. Fontes, P. Grillas, P. Lambret, D. Nicolas, A. Olivier and I.R. Geijzendorffer: Estimating biodiversity changes in the Camargue wetlands: An expert knowledge approach. PLOS ONE, 14, e0224235 (2019)

Garcia-Nieto, A.P., I. Geijzendorffer, F. Baró, P. Roche, A. Bondeau and W. Cramer: Impacts of urbanization around Mediterranean cities: Changes in ecosystem service supply. Ecol. Indic., 91, 589-606 (2018).

Garófano-Gomez V., F. Martınez-Capel, M. Peredo-Parada, E. Julia, O. Marın, M.R. Munoz, M.R. Soares Costa and J.L. Pinar-Arenas: Assessing hydromorphological and floristic patterns along a regulated Mediterranean river: The Serpis River (Spain). Limnetica, 30, 307-328 (2011).

Garófano-Gómez, V., F. Martínez-Capel, W. Bertoldi, A. Gurnell, J. Estornell and F. Segura Beltrán: Six decades of changes in the riparian corridor of a Mediterranean river: A synthetic analysis based on historical data sources. Ecohydrology, 6, 536-553 (2013).

Geijzendorffer, I.R., C. Beltrame, L. Chazee, E. Gaget, T. Galewski, A. Guelmami, C. Perennou, N. Popoff, C. Guerra, R. Leberger and J. Jalbert: A more effective Ramsar Convention for the conservation of Mediterranean wetlands. Front Ecol. Evol., 7, 21 (2019).

Gendaszek, A.S., C.S. Magirl and C.R. Czuba: Geomorphic response to flow regulation and channel and floodplain alteration in the gravelbedded Cedar River, Washington, USA. Geomorphology, 179, 258-268 (2012).

Genev, M.: Patterns of runoff change in Bulgaria. IAHS-AISH P., 280, 7985 (2003).

Giakoumakis, S.G. and G. Baloutsos.: Investigation of trend in hydrological time series of the Evinos River basin. Hydrolog. Sci. J., 42, 81-88 (1997).

Gober, P.: Desert urbanization and the challenges of water sustainability. Curr. Opin. Env. Sust., 2, 144-150 (2010).

González, E.M. Gonzàlez-Sanchis, A. Cabezas, F.A. Comin and E. Muller: Recent changes in the Riparian forest of a large regulated Mediterranean River: Implications for management. Environ. Manage., 45, 624-639 (2010).

Grantham, T.E., R. Figueroa and N. Prat: Water management in Mediterranean river basins: A comparison of management frameworks, physical impacts, and ecological responses. Hydrobiologia, 719, 451-482 (2013).

Hannah, D.M., S. Demuth, H.A.J. Van Lanen, U. Looser, C. Prudhomme, G. Rees, K. Stahl and L.M. Tallaksen: Large-scale river flow archives: importance, current status and future needs. Hydrol. Process., 25, 1191-1200 (2011).

Hejazi, M.I., J. Edmonds, L. Clarke, P. Kyle, E. Davies, V. Chaturvedi, M. Wise, P. Patel, J. Eom and K. Calvin: Integrated assessment of global water scarcity over the $21^{\text {st }}$ century under multiple climate change mitigation policies. Hydrol. Earth Syst. Sc., 18, 2859-2883 (2014).

Herrera, A.M. and T.L. Dudley: Reduction of riparian arthropod abundance and diversity as a consequence of giant reed (Arundo donax) invasion. Biol. Invasions, 5, 167-177 (2003).

lakovoglou, V., G.N. Zaimes and D. Gounaridis: Riparian areas in urban settings: Two case studies from Greece. In. J. Innov. Sust. Develop., 7, 271-288 (2013).

Iglesias, A., L. Garrote, S. Quiroga and M. Moneo:A regional comparison of the effects of climate change on agricultural crops in Europe. Climatic Change, 112, 29-46 (2012).

Ilhardt, B.L., E.S Verry and B.J. Palik: Defining riparian areas. In: 
Riparian Management in Forests of the Continental Eastern United States (Eds.: E.S. Verry, J.W. Hornbeck and C.A. Dolloff). Lewis Publishers, Boca Raton, FL, USA, pp. 23-42 (2000).

Jiménez-Ruiz, J. and M.I. Santín-Montanyá: An approach to the integrated management of exotic invasive weeds in riparian zones. In: Riparian Zones: Characteristics, Management Practices and Ecological Impacts (Ed.: O.S. Pokrovsky). Nova Science Pub Inc. Hauppage, NY, USA, pp. $99-124$ (2016).

Kahya, E. and S. Kalaycl: Trend Analysis of Streamflow in Turkey. J. Hydrol., 289, 128-144 (2004).

Kiernan, J.D., P.B. Moyle and P.K. Crain: Restoring native fish assemblages to a regulated California stream using the natural flow regime concept. Ecol. Appl., 22, 1472-1482 (2012).

Kontsiotis, V., G.N. Zaimes, S. Tsiftsis, P. Kiourtziadis and D. Bakaloudis: Assessing the influence of riparian vegetation structure on bird communities in agricultural Mediterranean landscapes. Agroforest. Syst., 93, 675-687 (2019).

Koutroulis, A.G., I.K. Tsanis, I.N. Daliakopoulos and D. Jacob: Impact of climate change on water resources status: a case study for Crete Island, Greece. J. Hydrol., 479, 146-158 (2013).

La Jeunesse, I., C. Cirelli, D. Aubin, C. Larrue, H. Sellami, S. Afifi, A. Bellin, S. Benabdallah, D.N. Bird, R. Deidda, M. Dettori, G. Engin, F. Herrmann, R. Ludwig, B. Mabrouk, B. Majone, C. Paniconi and A. Soddu: Is climate change a threat for water uses in the Mediterranean region. Results from a survey at local scale. Sci. Total Environ., 55, 981-996 (2015).

Lelieveld, J, P. Hadjinicolaou, E. Kostopoulou, J. Chenoweth, M.El. Maayar, C. Giannakopoulos, C. Hannides, M.A. Lange, M. Tanarhte, E. Tyrlis and E. Xoplaki: Climate change and impacts in the Eastern Mediterranean and the Middle East. Climatic Change, 114, 667-687 (2012).

Leo, M., J.A. Calleja, F. Lara, R. Garilleti and N.G. Medina: Drivers of plant richness patterns of Mediterranean riparian forests at local and regional scales have bottom-up and top-down effects. J. Veg. Sci., 30, 485-497 (2019).

Lespinas, F., W. Ludwig and S. Heussner: Hydrological and climatic uncertainties associated with modeling the impact of climate change on water resources of small Mediterranean coastal rivers. J. Hydrol., 511, 403-422 (2014)

Lobera, G., R.J Batalla, D. Vericat, J.A Lopez-Tarazin and A. Tena: Sediment transport in two Mediterranean regulated rivers. Sci. Total Environ., 540, 101-113 (2016).

Lowrance, R.R., R. Leonard and J. Sheridan: Managing riparian ecosystems to control nonpoint source pollution. J. Soil Water Conserv., 40, 87-91 (1985).

Magalhães, M.F., P. Beja, I.J. Schlosser and M.J. Collares-Pereira: Effects of multi-year droughts on fish assemblages of seasonally drying Mediterranean Streams. Fresh Water Biol., 52, 1494-1510 (2007).

Magdaleno, F. and R. Martinez: Evaluating the quality of riparian forest vegetation. The Riparian Forest Evaluation (RFV) index. For. Syst., 23, 259-272 (2014).

Majone, B., C.I. Bovolo, A. Bellin, S. Blenkinsop and H.J. Fowler: Modeling the impacts of future climate change on water resources for the Gállego river basin (Spain). Water Resour. Res., 48, W01512 (2012).

Malek, Ž., P.H. Verburg, I.R. Geijzendorffer, A. Bondeau and W. Cramer: Global change effects on land management in the Mediterranean region. Global Environ. Chang., 50, 238-254 (2018).

Marchane, A., Y. Tramblay, L. Hanich, D. Ruelland and L. Jarlan: Climate change impacts on 16 surface water resources in the Rheraya catchment (High Atlas, Morocco). Hydrol. Sci. J., 62, 979-995 (2017).
Mediterranean Wetlands Outlook 2:Solutions for sustainable Mediterranean Wetlands. Tour du Valat, France. (2018)

Mencio, A. and J. Mas-Pla: Influence of groundwater exploitation on the ecological status of streams in a Mediterranean system (S. Basin, N.E. Spain). Ecol. Indic., 10, 915-926 (2010).

Mourato, S., M. Moreira and J. Corte-Real: Water Resources Impact Assessment Under Climate Change Scenarios in Mediterranean Watersheds. Water Resour. Manag., 29, 2377-2391 (2015).

Moustadraf, J., M. Razack and M. Sinan: Evaluation of the impacts of climate changes on the coastal Chaouia aquifer, Morocco, using numerical modeling. Hydrogeol. J., 16, 1411-1426 (2008).

Nadal-Sala, D., F. Hartig, C.A Gracia and S. Sabat: Global warming likely to enhance black locust (Robinia pseudoacacia L.) growth in a Mediterranean riparian forest. Forest Ecol. Manag., 449,117448 (2019).

Naiman, R.J., H. Decamps and M.E. McClain: Riparia: Ecology, conservation, and management of streamside communities. Elsevier Acad. Press, London, UK (2005).

National Research Council: Wetlands: Characteristics and boundaries. Natl. Acad. Sci. Washington, DC, USA(1995).

National Research Council: Riparian areas: Functions and strategies for Management. Natl. Acad. Sci. Washington, DC, USA(2002).

Navarro-Ortega, A., V. Acuña, A. Bellin, P. Burek, G. Cassiani, R. ChoukrAllah, S. Dolédec, A. Elosegi, F. Ferrari, A. Ginebreda, P. Grathwohl, C. Jones, P.K. Rault, K. Kok, P. Koundouri, R.P. Ludwig, R. Merz, R. Milacics and D. Barceló: Managing the ef-fects of multiple stressors on aquatic ecosystems under water scarcity. The GLOBAQUA project. Sci. Total Environ., 503-504, 3-9 (2015).

Nilsson, C., C.A. Reidy, M. Dynesius and C. Revenga: Fragmentation and flow regulation of the world's large river systems. Science, 308, 405-408 (2005).

Nunes, A.G. Oliveira, T. Mexia, A. Valdecantos, C. Zucca, E.A.C. Costantini, E.M. Abraham, A.P. Kyriazopoulos, A. Salah, R. Prasse, O. Correia, S. Milliken, B. Kotzen and C. Branquinho: Ecological restoration across the Mediterranean Basin as viewed by practitioners panel. Sci. Total Environ., 566-567, 722-732 (2016).

Olson, D.M., E. Dinerstein, E.D. Wikramanayake, N.D. Burgess, G.V.N. Powell, E.C. Underwood, J.A. D'amico, I. Itoua, H.E. Strand, J.C. Morrison, C.J. Loucks, T.F. Allnutt, T.H. Ricketts, Y. Kura, J.F. Lamoreux, W.W. Wettengel, P. Hedao and K.R. Kassem: Terrestrial Ecoregions of the World: A New Map of Life on Earth. Bio Science, 51, 933 (2001).

Ouhamdouch, S., M. Bahir, D. Ouazar, A. Goumih and K. Zouari: Assessment the climate change impact on the future evapotranspiration and flows from a semi-arid environment. Arab. J. Geosci., 13, 82 (2020).

Papastergiadou, E., K. Stefanidis, G. Dorflinger, E. Giannouris, K. Kostara and P. Manolaki: Exploring biodiversity in riparian corridors of a Mediterranean island: Plant communities and environmental parameters in Cyprus rivers. Plant Biosyst., 150, 91-103 (2016).

Pausas, J.G. and F. Lloret: Spatial and temporal patterns of plant functional types under simulated fire regimes. Int. J. Wildland Fire, $16,484(2007)$

Piras, M., G. Mascaro, R. Deidda and E.R. Vivoni: Quantification of hydrologic impacts of climate change in a Mediterranean basin in Sardinia, Italy, through high-resolution simulations. Hydrol. Earth Syst. Sci., 18, 5201-5217 (2015).

Rault, P.A., P. Koundouri, E. Akinsete, R. Ludwig, V. Huber-Garcia, S. Tsani, V. Acuna, E. Kalogianni, J. Luttik, K. Kokg, N. Skoulikidis and J. Froebrich: Down scaling of climate change scenarii to river basin level: A transdisciplinary methodology applied to Evrotas river basin, Greece. Sci. Total Environ., 660, 1623-1632 (2019). 
Resh, V.H., L.A. Bêche, J.E. Lawrence, R.D. Mazor, E.P. McElravy, A.P. O'Dowd, D. Rudnick and S.M. Carlson: Long-term population and community patterns of benthic macroinvertebrates and fishes in Northern California Mediterranean-climate streams. Hydrobiologia, 719, 1, 93-118 (2013).

Rivas, B.L. and I. Koleva-Lizama: Influence of climate variability on water resources in the Bulgarian South Black Sea basin. IAHS-AISH P., 296, 81-88 (2005).

Rouissi, M., S.D Muller., B.H. Jilani, Z. Ghrabi-Gammar, L. Paradis, M. Bottollier-Curtet, E. Gerbaud, A. Daoud-Bouattour: History and conservation of Tunisia's largest freshwater wetland: GarâaSejenane. Rev. Palaeobot. Palyno., 257, 43-56 (2018).

Sabater, S., A. Elosegi, V. Acuña, A. Basaguren, I. Muñoz and J. Pozo: Effect of climate on the trophic structure of temperate forested streams. A comparison of Mediterranean and Atlantic streams. Sci. Total Environ., 390, 475-484 (2008).

Salinas, M.J. and J.J. Casas: Riparian vegetation of two semi-arid Mediterranean rivers: Basin-scale responses of woody and herbaceous plants to environmental gradients. Wetlands, 27, 831-845 (2007).

Santos, M.J.: Encroachment of upland Mediterranean plant species in riparian ecosystems of southern Portugal. Biodivers. Conserv., 19, 2667-2684 (2010)

Savopoulou, A., G. Giatas, G. Pagonis, V. lakovoglou and G.N. Zaimes: Visual protocols and GIA as preliminary investigative tools to locate potential ecoengineering in streams and riparian areas. Procedia Environ. Eng. Manag. J., 4, 227-234 (2017).

Schismenos, S., G.N. Zaimes, V. lakovoglou and D. Emmanouloudis: Environmental sustainability and ecotourism of riparian and deltaic ecosystems: opportunities for rural Eastern Macedonia and Thrace, Greece. Int. J. Environ. Stud., 76, 675-688 (2019).

Schultz, R.C., T.M. Isenhart, W.W. Simpkins and J.P. Colletti: Riparian forest buffers in agroecosystems - Lessons learned from the Bear Creek Watershed, Central lowa, USA. Agroforest. Syst., 61, 35-50 (2004).

Sen, Z.: Wadi Hydrology. CRC Press, Boca Raton, FL., USA(2019)

Shaban, A.: Indicators and Aspects of Hydrological Drought in Lebanon. Water Resour. Manag., 23, 1875-1891 (2009).

Smiatek, G., H. Kunstmann and A. Heckl: High-resolution climate change impact analysis on expected future water availability in the upper Jordan catchment and the Middle East. J. Hydrometeorol., 15, 1517-1531 (2014).

Stella, J.C., P.M. Rodríguez-González, S. Dufour and J. Bendix: Riparian vegetation research in Mediterranean-climate regions: common patterns, ecological processes, and considerations for management. Hydrobiologia, 719, 291-315 (2013).

Srivastava, P. and S. Singh: Conservation of soil, water and nutrients in surfacerunoff using riparian plant species. J. Environ. Biol., 33, 4349 (2012).

Terrado, M., V. Acuna, D. Ennaanay, T. Tallis and S. Sabater: Impact of climate extremes on hydrological ecosystem services in a heavily humanized Mediterranean basin. Ecol. Indic., 37, 199-209 (2014).

Tramblay, Y., D. Ruelland, L. Hanich and H. Dakhlaoui: Hydrological impacts of climate change in North African countries. In: The Mediterranean Region under Climate Change. A Scientific Update, (Eds.: S. Thiébault and J-P. Moatti). IRD Éditions, AllEnvi,
Marseille, France, pp. 295-302 (2016).

United Nations, Department of Economic and Social Affairs, Population Division: World Population Prospects: The 2012 Revision, Highlights and Advance Tables. Working Paper No. ESA/P/WP 228, United Nations, New York, NY, USA(2013).

Vallejo, V.R., A. Smanis, E. Chirino, D. Fuentes, A. Valdecantos and A. Vilagrosa: Perspectives in dryland restoration: approaches for climate change adaptation. New Forest, 43, 561-579 (2012).

Van den Broeck, M., A. Waterkeyna, L. Rhazi, P. Grillas and L. Brendoncka: Assessing the ecological integrity of endorheic wetlands, with focus on Mediterranean temporary ponds Maarten. Ecol. Indic., 54, 1-11 (2015).

Vericat, D. and R.J. Batalla: Sediment transport in a large impounded river: The lower Ebro, NE Iberian Peninsula. Geomorphology, 79, 72-92 (2006).

Zaimes, G.N., V. lakovoglou, D. Emmanouloudis and D. Gounaridis: Riparian Areas of Greece: Their Definition and Characteristics: Journal of Engineering Science and Technology Review, 3,176$183(2010)$

Zaimes, G.N., D. Gounarids, V. lakovoglou and D. Emmanouloudis: Riparian area studies in Greece: A literature review: Fresen. Environ. Bulletin., 20, 1470-1477 (2011a).

Zaimes, G.N., K.H. Lee, M. Tufeckioglu, L.A. Long, R.C. Schultz, T.M. Isenhart. The Effectiveness of Riparian Conservation Practices in Reducing Sediment in lowa Streams. In: Agricultural Research Updates (Ed.: B.P. Hendriks). Vol. 2 Nova Science Publishers, Hauppage, NY, USA, pp. 117-166 (2011b).

Zaimes, G.N. and D. Emmanouloudis: Sustainable management of the freshwater resources of Greece: J. Engi. Sci. Technol. Rev., 5, 7782 (2012).

Zaimes, G.N., D. Arthun and V. Liordos: Population trends of the native fish assemblage in Bonita Creek, Arizona, USA. West. N. Am. Naturalist, 79, 394-402 (2019a).

Zaimes, G.N., D. Gounaridis and E. Symeonakis: Assessing the impact of dams on riparian and deltaic vegetation using remotely-sensed vegetation indices and Random forests modelling. Ecol. Indic., 103, 630-641 (2019b).

Zaimes, G.N., P. Loisios, P. Fytopoulos, C. Mersina, N. Fyllas, V. lakovoglou and D. Avtzis: Ground dwelling insects as environmental indicators of riparian habitats in agricultural Mediterranean landscapes. Environ. Eng. Manag. J., 18, $1977-$ 1986 (2019c).

Zaimes, G.N., G. Tardio, V. lakovoglou, M. Gimenez, J.L. GarciaRodriguez and P. Sangalli: New tools and approaches to promote soil and water bioengineering in the Mediterranean. Sci. Total Environ., 693, 133677 (2019d).

Zaimes, G.N., M. Tufekcioglu and R.C. Schultz: Riparian Land-Use Impacts on Stream Bank and Gully Erosion in Agricultural Watersheds: What We Have Learned. Water 11, 1343 (2019e).

Zogaris, S., Y. Chatzinikolaou, P. Dimopoulos: Assessing environmental degradation of montane riparian zones in Greece. J. Environ. Biol., 30, 719-726 (2009)

Zogaris, S., V. Hatzivarsanis, A.N. Ecomomou, Y. Hatznikolaou, S. Giakoumi and P. Dimopoulos: Riparian zones in Greece: Protecting riverine oasis of life. IIW and HCMR. Athens, Greece (2007). 